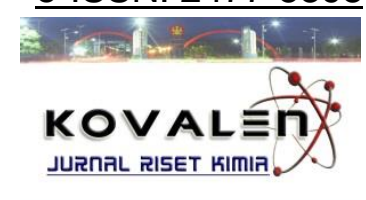

\title{
PRODUKSI METIL OLEAT MELALUI REAKSI METANOLISIS MINYAK BIJI KELOR (Moringa oleifera Lam)
}

\section{[Production of Methyl Oleat Through Methanolysis Reaction of Moringa (Moringa oleifera Lam) Seed Oil]}

\author{
Fathiah Riskah $^{1 *}$, Ahmad Ridhay ${ }^{1}$, Mappiratu ${ }^{1}$, Erwin Abd. Rahim ${ }^{1}$ \\ 1) Jurusan Kimia, Fakultas MIPA, Universitas Tadulako, Palu \\ Jl. Soekarno Hatta Km.9, Kampus Bumi Tadulako Tondo Palu, Telp. 0451- 422611 \\ *)Coresponding author: fathiajufri@gmail.com
}

Diterima 10 November 2018, Disetujui 11 Januari 2019

\begin{abstract}
The objective of this research is in getting the highest mass fraction of oleat acid methyl ester of Moringa seed oil/methanol ratio $(\mathrm{v} / \mathrm{v})$ and the reaction time in methanolisis of Moringa seed oil and to determine the composition of methyl ester oleat acid. The completely randomized design (CRD) was used in this research with 5 variations of Moringa oleifera lam seed oil/methanol ratio and 5 variations of reaction time $(1: 3,1: 4,1: 5,1: 6,1: 7(\mathrm{v} / \mathrm{v})$ and $30,60,90,120$ and 150 minutes, respectively). The result showed that increasing the ratio of moringa oleifera lam seed oil/methanol will increase the mass fraction of oleat acid methyl ester with the maximum mass fraction $(72.61 \%)$ in the ratio of $1: 7$ $(\mathrm{v} / \mathrm{v})$ of Moringa oleifera seed oil/methanol. The same result trend is also found by increasing reaction time. It gave the maximum mass fraction (78.75\%) in 150 minutes of reaction time. The result of GCMS revealed that oleat acid methyl ester has three components where the most dominant component is methyl oleat $(48.25 \%)$, followed by methyl stearat $(7.67 \%)$, methyl palmitat $(5.14 \%)$ and unknown compound is $38.94 \%$.
\end{abstract}

Keywords: Moringa oleifera Lam seed oil, methyl oleat, methanolisis

\begin{abstract}
ABSTRAK
Telah dilakukan penelitian yang bertujuan untuk mendapatkan fraksi massa metil ester asam oleat tertinggi dari rasio minyak biji kelor/metanol $(\mathrm{v} / \mathrm{v})$ serta waktu reaksi dalam proses metanolisis minyak biji kelor serta komposisi dari metil ester asam oleat. Penelitian ini dilakukan dengan menggunakan Rancangan Acak Lengkap (RAL) dengan variasi rasio minyak biji kelor/metanol 1:3, 1:4, 1:5, 1:6 dan $1: 7(\mathrm{v} / \mathrm{v})$ serta variasi waktu reaksi 30 menit, 60 menit, 90 menit, 120 menit dan 150 menit. Hasil yang diperoleh menunjukkan bahwa peningkatan rasio minyak biji kelor/metanol meningkatkan fraksi massa metil ester asam oleat dengan fraksi massa maksimum (72.61\%) terdapat pada penggunaan rasio minyak biji kelor/metanol $1: 7(\mathrm{v} / \mathrm{v})$. Demikian pula pada pengaruh waktu reaksi yang menunjukkan bahwa peningkatan waktu reaksi meningkatkan fraksi massa metil ester asam oleat dengan fraksi massa maksimum (78.75\%) terdapat pada penggunaan waktu reaksi 150 menit. Berdasarkan hasil analisis GC-MS diperoleh senyawa dominan penyusun metil ester tersebut adalah metil oleat persentase sebesar $48.25 \%$, kemudian metil stearat dengan persentase sebesar $7.67 \%$, selanjutnya metil palmitat dengan persentase sebesar 5.14 dan senyawa yang belum diketahui secara pasti dengan persentase sebesar $38.94 \%$
\end{abstract}

Kata Kunci: Minyak biji kelor, metil oleat,metanolisis 


\section{LATAR BELAKANG}

Senyawa metil ester asam lemak merupakan adalah kelompok senyawa ester yang diperoleh dari reaksi antara dari asam lemak baik lemak hewani atau minyak nabati dengan senyawa alkohol. Metil ester asam lemak tekah lama dikembangkan dan dimanfaatkan dalam berbagai industri kimia, seperti subtitusi bahan bakar diesel, industri kosmetika, pembuatan zat adiktif makanan, pembuatan lemak alkohol, zat antara industri farmasi, dan pembuatan poliester amida (Aritonang dan Surbakti, 2004)

Salah satu bahan yang berpotensi menjadi bahan baku utama pembuatan metil ester diantaranya adalah minyak biji kelor. Kelor (Moringa oleiferaLam) merupakan tanaman yang tergolong dalam famili Moringaceae. Nasir et al. (2010) melaporkan bahwa kadar minyak yang terdapat dalam minyak biji kelor dapat mencapai $35,83 \%$ dengan kandungan tertinggi berupa asam oleat dalam bentuk trans sebesar 58,50\%. Minyak biji kelor memiliki beberapa kandungan asam lemak dengan komposisi tertinggi adalah asam oleat sebesar $72,2 \%$, asam behenic $7,1 \%$, asam palmitat $6,5 \%$, asam stearat $6,0 \%$, asam arakhidat $4,0 \%$ dan asam linoleat 1,0\% (Gunstone et al., 2007 dalam Nasir et al., 2010).

Metil oleat menjadi salah satu bahan yang sangat dibutuhkan saat ini karena peranannya sebagai bahan baku asam oleat dan triolein. Triolein merupakan senyawa yang biasanya digunakan untuk mempelajari absorbsi lemak dalam tubuh manusia dalam bidang kedokteran. Asam lemak jenis oleat adalah monounsaturated fatty acid atau memiliki satu ikatan rangkap. Asam lemak tersebut dapat menurunkan kadar kolesterol darah, menurunkan resiko serangan jantung koroner serta dapat mengurangi resiko kardiovaskular dan juga stroke karena mampu menurunkan kadar LDL, trigliserida serta menaikkan kadar HDL. (Dwiputra et al., 2015).

Dalam proses produksi metil ester asam oleat terdapat beberapa faktor yang mempengaruhi hasil produksi. Faktor faktor yang mempengaruhi produk metil ester asam oleat diantaranya adalah perbandingan rasio molar reaktan dan waktu reaksi (Hui, 1996 dalam Widayanto, 2007).Reaksi transesterifikasi minyak biji kelor yang mengandung asam oleat menjadi metil esternya merupakan reaksi yang bersifat reversibel sehingga produk yang dihasilkan tidak selalu dapat mengikuti analisis stoikiometrinya. Kondisi reaksi transesterifikasi yang menghasilkan produk dalam jumlah maksimum dapat diperoleh menggunakan rasio molar yang tepat. Kenaikan rasio molar antar reaktan akan mengakibatkan kecepatan reaksi meningkat, sehingga kesetimbangan bergeser ke arah produk sehingga memaksimalkan jumlah produk yang terbentuk (Rasidi, 2004 dalam Usman et al., 2009. 
Darnoko et al. (2002) dalam Arbianti et al (2008) menyimpulkan bahwa waktu reaksiberbanding lurus dengan konsentrasi metillaurat yang dihasilkan. Semakin lama waktu reaksi metanolisis semakin tinggi pula fraksi massa metil ester asam lemak yang terbentuk, dan pada waktu reaksi tertentu, rendemen metil ester asam lemak mencapai maksimum yaitu 79\% (Purwati, 2009). Hasil analisis Auwalina (2010) menunjukkan bahwa dengan adanya peningkatan waktu reaksi pada proses transesterifikasi menghasilkan fraksi massa metil ester asam lemak yang lebih tinggi dimana fraksi massa tertinggi diperoleh pada waktu reaksi 60 menit yaitu sebesar 100\%. Purwati (2009) mendapatkan fraksi massa metil ester tertinggi $95,28 \%$ pada reaksi metanolisis minyak kelapa pada penggunaan waktu reaksi 60 menit. Berdasarkan beberapa kajian diatas maka perlu dilakukan penelitian mengenai rasio metanol terhadap minyak biji kelor serta waktu reaksi yang optimal untuk mendapatkan fraksi massa tertinggi serta komposisi metil ester untuk mengetahui kandungan metil ester yang terbentuk.

\section{METODE PENELITIAN}

\section{Bahan dan Peralatan}

Bahan yang digunakan dalam penelitian ini adalah biji kelor sebagai bahan dasar dan bahan lain sebagai bahan penunjang dalm reaksi esterifikasi metanolisis dan analisis antara lain: $n$ - heksan, Asam Klorida, Natrium Hidroksida, aquadest, metanol p.a (E merck), natrium sulfat anhidrat, Plat TLC silica gel G60 F254 ukuran $20 \times 20 \mathrm{~cm}$. Sedangkan peralatan yang digunakan antara lain ekstraktor soxhlet, mesin kocok, neraca analitik, rotary evaporator, labu erlenmeyer, corong pisah, statif dan klem, chamber, stopwatch, GC-MS serta alat-alat gelas yang umum digunakan dalam laboratorium kimia.

\section{Prosedur Penelitian}

\section{Preparasi sampel}

Metode preparasi bahan yang digunakan merupakan modifikasi dari metode ekstraksi minyak biji kelor oleh Nasir et al. (2010). Pada tahap persiapan bahan baku pertama-tama buah kelor dikupas kulitnya, kemudian dikeringkan. Tujuan pengeringan ini antara lain untuk mengurangi kandungan air dalam biji dan mempermudah dalam proses penghancuran. Pada penelitian ini biji kelor yang telah kering di haluskan menggunakan blender hingga jadi tepung dan diayak dengan menggunakan ayakan 60 mesh.

\section{Ekstraksi minyak biji kelor}

Metode ekstraksi yang digunakan merupakan modifikasi dari metode ekstraksi Minyak atsiri Daun Zodia (Evodia Suaveolens) oleh Handayani dan Nurcahyanti (2015). Bahan dimasukkan ke dalam pelarut n-Heksan dengan perbandingan 1:10 dan dimaserasi selama 
$3 \times 24$ jam. Kemudian hasil ekstraksi diuapkan pelarutnya secara vakum untuk recovery pelarut $\mathrm{n}$-Heksan. Minyak biji kelor yang dihasilkan ditimbang dan ditentukan rendemennya serta disimpan dalam wadah gelas berwarna coklat sebelum ditransesterifikasi.

$\%$ Rendemen $=\frac{\text { Berat minyak hasil }}{\text { Berat biji kelor }} \times 100 \%$

\section{Tahap degumming (Sari, 2007)}

Minyak yang telah dihasilkan harus di degumming terlebih dahulu guna untuk menghilangkan senyawa pengotor yang terkandung didalam minyak, dengan cara minyak dipanaskan sampai suhu $90{ }^{\circ} \mathrm{C}$ selama 30 menit kemudian ditambahkan air panas bersuhu $60{ }^{\circ} \mathrm{C}$ dan diaduk. Air dipisahkan dari minyak menggunakan corong pemisah.Setelah itu ke dalam minyak ditambahkan air lagi dan dikocok.Tahap ini diulang sampai air cucian bersifat netral.

\section{Transesterifikasi minyak biji kelor}

Penelitian ini dilaksanakan secara bertahap yang terdiri dari tahap pengaruh rasio metanol terhadap minyak biji kelor, dan tahap pengaruh waktu reaksimenggunakan modifikasi metode Purwati (2009).

\section{Pengaruh Rasio Minyak Kelor/Metanol (v/v)}

Biji

Rasio minyak biji kelor/metanol yang diterapkan terdiri atas lima tingkatan masing-masing $1: 3 ; 1: 4 ; 1: 5 ; 1: 6$ dan $1: 7$ atas dasar volume pervolume (v/v). Reaksi berlangsung di atas mesin kocok agitasi 250 rpm selama 1,5 jam menggunakan katalis natrium hidroksida $2 \%$ dalam metanol. Reaksi dihentikan dengan menggunakan $\mathrm{HCl} 6 \mathrm{~N}$. Produk reaksi dimasukkan ke dalam corong pemisah dan dibiarkan hingga terbentuk dua lapisan.Lapisan bawah (gliserol dan metanol sisa) ditampung, sedangkan lapisan atas (metil ester asam lemak dan produk samping) dicuci dengan air kemudian dilewatkan pada natrium sulfat anhidrat dengan tujuan untuk menghilangkan air yang terikut.

\section{Pengaruh waktu reaksi}

Waktu reaksi yang diterapkan terdiri atas lima tingkatan waktu reaksi masingmasing 0.5 jam ; 1 jam ; 1,5 jam; 2 jam dan 2,5 jam. Reaksi berlangsung di atas mesin kocok menggunakan katalis natrium hidroksida $2 \%$ dalam metanol.Reaksi dihentikan dengan menggunakan $\mathrm{HCl} 6 \mathrm{~N}$. Produk reaksi dimasukkan ke dalam corong pemisah dan dibiarkan hingga terbentuk dua lapisan. Lapisan bawah (gliserol dan metanol sisa) ditampung, sedangkan lapisan atas (metil ester asam lemak dan produk samping) dicuci dengan air kemudian dilewatkan pada natrium sulfat anhidrat dengan tujuan untuk menghilangkan air yang terikat.

\section{Analisis Kromatografi Lapis Tipis Preparatif}

Metil ester asam oleat dalam produk reaksi bebas air dianalisis fraksi massanya menggunakan metode kromatografi lapis 
tipis preparatif. Eluen yang digunakan dalam pelaksanaan elusi yaitu campuran heksana / dietil eter / asam formiat (80: 20 : 2) atas dasar v/v/v (Mappiratu, 1999). Penampak noda digunakan iodium kristal. Setelah dilakukan elusi dan penampakan noda, fraksi komponen metil ester asam oleat dihitung menggunakan persamaan :

Fraksi Massa $=\frac{\text { Berat noda metil ester }}{* \text { Berat noda total }} \times 100 \%$

\section{Analisis GC-MS}

Metil ester yang dihasilkan dari penggunaan kondisi terbaik dianalisis kandungan metil oleatnya menggunakan metode GC-MS (Gas ChromatographyMass Spectrophotometry).

\section{HASIL DAN PEMBAHASAN}

\section{Hasil Metanolisis pada Pengaruh Rasio Minyak Biji Kelor/Metanol (v/v)}

Untuk mengetahui pengaruh rasio metanol terhadap minyak biji kelor yang menghasilkan metil ester asam oleat dengan fraksi massa tertinggiditerapkan berbagai rasio minyak biji kelor terhadap metanol (v/v). Fraksi massa metil ester asam oleat yang dihasilkan berkolerasi positif dengan meningkatnya rasio minyak biji kelor terhadap metanol yang digunakan (Gambar 1). Fraksi massa metil ester asam oleat tertinggi (72.61\%) terdapat pada penggunaan rasio minyak biji kelor terhadap metanol 1:7 (v/v), sedangkan fraksi massa metil ester asam oleat terendah (24.65\%) ditemukan pada penggunaan rasio 1:3 (v/v).

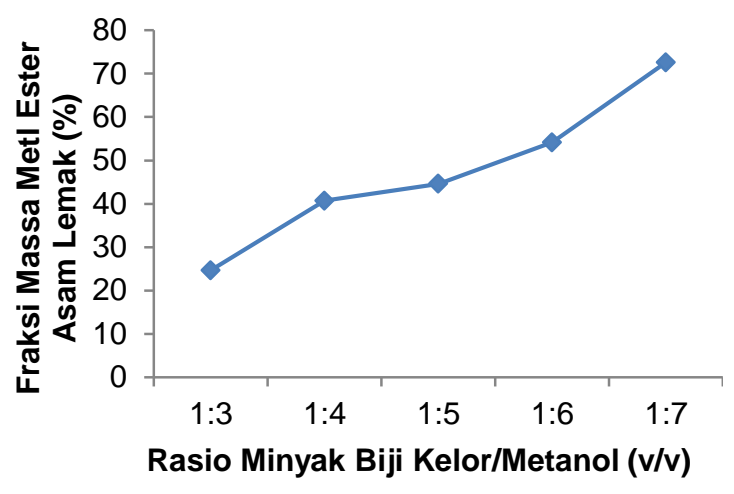

Gambar 1 Grafik hubungan rasio minyak biji kelor/metanol (v/v) terhadap Fraksi Massa MEAL

Hasil yang diperoleh belum menunjukkan keadaan maksimum yang ditandai dengan nilai fraksi massa yang masih meningkat relatif terhadap peningkatan penggunaan metanol. Hal tersebut diduga karena penggunaan metanol yang masih kurang sehingga tidak dapat mengesterkan seluruh asam oleat minyak biji kelor yang direaksikan, serta tingkat kenetralan minyak biji kelor yang masih rendah sehingga diperlukan rasio reaktan yang lebih tinggi. Freedman et al. (1984) telah menemukan reaksi alkoholisis dalam kondisi basa mampu menghasilkan keberhasilan reaksi mencapai 99\% pada suhu $60^{\circ} \mathrm{C}$ selama 1 jam atau lebih dengan rasio mol metanol terhadap minyak sawit adalah $6: 1$, tetapi dengan syarat minyak atau lemak yang digunakan harus dalam kondisi netral dan bebas air (Widayanto, 2007).

Hasil analisis sidik ragam dengan taraf kepercayaan $95 \% \quad(\alpha=0,05)$ menunjukkan bahwa rasio molar minyak biji kelor/metanol (v/v) berpengaruh nyata terhadap \% fraksi massa yang dihasilkan. 
Hasil uji lanjut menggunakan BNJ dengan taraf kepercayaan 95\% $\quad(\alpha=0,05)$ menunjukkan bahwa rasio minyak biji kelor/metanol 1:3, 1:4, 1:5, 1:6 dan 1:7 berbeda nyata. Maka rasio terbaik untuk diaplikasikan ke dalam variasi waktu reaksi adalah 1:7 minyak biji kelor/metanol $(\mathrm{v} / \mathrm{v})$.

\section{Waktu Reaksi Metanolisis Minyak Biji Kelor}

Untuk mengetahui pengaruh waktu reaksi terhadap fraksi massa metil ester asam oleat maka telah diterapkan berbagai variasi waktu reaksi.

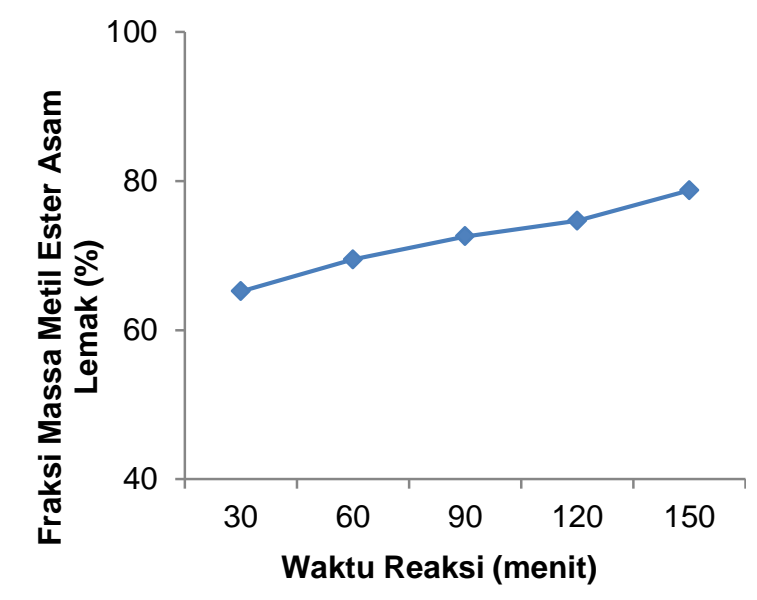

Gambar 2 Grafik hubungan waktu reaksi (menit) terhadap fraksi massa

Fraksi massa metil ester asam oleat yang dihasilkan berkolerasi positif dengan bertambahnya waktu reaksi (Gambar 2). Fraksi massa metil ester asam oleat tertinggi $(78,75 \%)$ pada penelitian ini terdapat pada penggunaan waktu reaksi 150 menit, sedangkan fraksi massa metil esterasam oleat terendah (65,19\%) ditemukan pada penggunaan waktu reaksi 30 menit.
Hasil yang diperoleh belum menunjukkan keadaan optimum yang ditandai dengan nilai fraksi massa yang masih meningkat relatif terhadap peningkatan waktu reaksi. Menurut Purwati (2009) hal tersebut diduga disebabkan oleh waktu reaksi yang masih relatif singkat sehingga masih banyak produk antara (monoasilgliserol dan diasilgliserol) yang belum berubah menjadi metil ester. Demikian pula masih terdapat minyak atau triasilgliserol yang belum bereaksi dengan alkohol membentuk metil ester.

Hasil analisis sidik ragam dengan taraf kepercayaan 95\% $(\alpha=0,05)$ menunjukkan bahwa waktu reaksi berpengaruh nyata terhadap fraksi massa metil oleat. Oleh karena itu dapat dilakukan analisis lanjut dengan uji BNJ untuk menentukan waktu reaksi terbaik. Dari hasil uji lanjut BNJ dengan taraf kepercayaan $95 \% \quad(\alpha=0,05)$, dapat disimpulkan bahwa waktu reaksi 30 menit, 60 menit, 90 menit, 120 menit dan 150 menit berbeda nyata.

\section{Komposisi Metil Ester Asam oleat}

Analisis sampel metil ester asam oleat menggunakan GC-MS menghasilkan sebuah spektogram yang merepresentasikan komposisi dari seluruh senyawa penyusun sampel minyak tersebut.

Kromatogram memberikan minimum terdapat 4 puncak. Puncak kromatogram tersebut mengindikasikan bahwa minimal 
terdapat 4 senyawa penyusun sampel metil ester tersebut (Tabel 1).

Tabel 1 Interpretasi spektrum GC-MS

\begin{tabular}{clcc}
\hline No & Nama senyawa & RT & $\begin{array}{c}\text { Luas } \\
\text { area }\end{array}$ \\
\hline 1 & Metil oleat & 44,81 & 6644870 \\
2 & Metil palmitat & 40,91 & 707690 \\
3 & Metil stearate & 44,80 & 1056304 \\
4 & Belum diketahui & 44,18 & 5362323 \\
\hline
\end{tabular}

Berdasarkan analisis data diketahui bahwa terdapat 4 senyawa peyusun sampel, dimana senyawa dominan penyusun metil ester tersebut adalah metil oleat dengan persentase 48.25\%, kemudian metil palmitat $5.14 \%$, metil stearat $7.67 \%$, dan terdapat senyawa yang belum diketahui secara pasti dengan persentase $38.94 \%$

\section{KESIMPULAN}

Rasio molar minyak biji kelor/metanol (v/v) yang terbaik diperoleh pada penggunan rasio $1: 7(\mathrm{v} / \mathrm{v})$ dengan fraksi massa sebesar $72,61 \%$, sedangkan waktu reaksi yang terbaik diperoleh pada perlakuan 150 menit dengan fraksi massa sebesar 78,75\%. Berdasarkan hasil analisis GC-MS diperoleh senyawa dominan penyusun metil ester tersebut adalah metil oleat dengan persentase sebesar 48,25\%, kemudian metil stearat dengan persentase sebesar 7,67\%, selanjutnya metil palmitat dengan persentase sebesar $5,14 \%$ dan senyawa yang belum diketahui secara pasti dengan persentase sebesar $38,94 \%$

\section{DAFTAR PUSTAKA}

Aritonang, H.F., and M. Br. Surbakti, 2004.Separation of Lauric Acid From Coconut Oil Using Crystalization Method With Acetone Solvent, Eugenia 10 (2): 195 - 204

Arbianti, R., Utami, T.S., dan N. Astri. 2008. Isolasi Metil Laurat Dari Minyak Kelapa Sebagai Bahan Baku Surfaktan Fatty Alcohol Sulfate (FAS). Makara Teknologi, 12 (2): 61 - 64

Auwalina, R. 2010. Produksi Gliserol, Metil Ester Asam Lemak Rantai Sedang dan Rantai Panjang dari Virgin Coconut Oil (VCO). Skripsi. Palu: Fakultas Matematika dan IImu Pengetahuan Alam UNTAD.

Dwiputra, D., Jagat, A. N., Wulandari, F. K., Prakarsa, A. S., Puspaningrum, D. A., Islamiyah, F. 2015. Minyak Jagung Alternatif Pengganti Minyak yang Sehat. Jurnal Aplikasi Teknologi Pangan 4 (2).

Freedman, B.,Eh, Pryde.,dan TI, Mounts. 1984. Variables Affecting the Yields of Fatty Esters from Transesterified Vegetable Oils. J. Am. Oil Chem. Soc. 61:1638-1643.

Handayani, P.S. dan Nurcahyati, H. 2015. Ekstraksi Minyak Atsiri Daun Zodia (Evodia Suaveolens) Dengan Metode Maserasi dan Distilasi Air. Jurnal Bahan Alam Terbarukan 4 (1).

Mappiratu.1999. Penggunaan Biokatalis Dedak Padi dalam Biosintesis Antimikroba Monoasilgliserol dari Minyak Kelapa. Disertasi. Program Pascasarjana Institut Pertanian Bogor. Bogor. 
Nasir, Subriyer., Delfi Fatina Soraya., dan Dewi Pratiwi. 2010. Pemanfaatan Ekstrak Biji Kelor (Moringa oleifera) Untuk Pembuatan Bahan Bakar Nabati. Jurnal 2nd AvoER Seminar. Palembang: Universitas Sriwijaya.

Purwati, I. 2009. Kajian Komposisi dan Waktu Reaksi Metanolisis dalam Sintesis Metil Ester Asam Lemak dari Minyak Kelapa. Skripsi. Palu: Fakultas Matematika dan IImu Pengetahuan Alam. Universitas Tadulako.

Sari, Ariza Budi Tunjung. 2007. Proses Pembuatan Biodiesel Minyak Jarak Pagar (Jatropha curcas L.) dengan Transesterifikasi Satu dan Dua Tahap. Skripsi. Bogor: Institut Pertanian Bogor.
Usman, T., Ariany, L., Rahmalia, W., dan Advant, R. 2009.Esterifikasi Asam Lemak dari Limbah Kelapa Sawit (Sludge Oi) Menggunakan Katalis Tawas.Indo. J. Chem. 2009. 9 (3). 474 $-478$.

Widayanto, Eko. 2007. Optimasi Pemekatan Karotenoid pada Metil Ester Kasar (Crude Methyl Ester) Minyak Sawit dengan Menggunakan Metode Kromatografi Kolom Adsorpsi. Skripsi. Bogor: Institut Pertanian Bogor. 